\title{
Case Studies In Marketing Research
}

Donald K. Hsu, (Email: yanyou@hotmail.com), Dominican College

\begin{abstract}
The use of case studies for Marketing Research has been examined. Starting with a topic selection, students collected the background information from various sources. A focus group was conducted to gather detailed information. A questionnaire was designed for an in-depth survey of the general public. Using mall intercept, 100 or more convenient samples were collected from the questionnaire. SPSS software was used to analyze this data. Then a final report with possible recommendations was written. During the course of this research, students made face-to-face interview with senior managers or CEO, selected appropriate Harvard Business School cases, did research using Internet or library resources, and added much real-life learning to the theoretical in-class knowledge.
\end{abstract}

\section{INTRODUCTION}

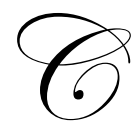

ase studies in Marketing Research have attracted much interest for global researchers. During the last two years, participants at the European Applied Business Research Conference presented findings in marketing related topics: 56 papers in 2003 and 25 papers in 2004. Out of the 81 papers, 24 reported work on marketing research. Cho and Ha (2004) measured consumer behavior by surveying 300 people on two brand names, Chow et al (2003) studied the environment friendly (eco-label) issues on the purchasing, Chuchinprakarn (2004) studied the on-line shopping intention of employees in Thailand, Ergin et al (2004) provided a field study on monthly grocery expenses of Turkish family, Eriotis et al (2004) used the profit approach to study marketing and power issues of the Greek and multinational firms which operate in Greece, Jee and Kim (2004) surveyed Korea consumers on portable internet services, Khatibi et al (2003) discussed the problems and barriers of the E-commerce adoption in Malaysia, Manna and Smith (2003) used correlations, ANOVA and regression techniques to measure the theoretical paradigm shift to relational marketing, Mitchell and Yates (2003) did a survey at a county fair, Mina (2003) studied the usage of mobile services, Mujika-Alberdi and Garcia-Arrizabalaga (2004) did a comparative study of the attitude toward advertising in Spain, Radas (2003) did an analysis of the survey on the case of Croatia, Reardon and Vida (2003) examined the factors in purchasing behaviors in transitional economies, Stevenson and Plath (2003) analyzed the Hispanic American financial services market, Ray (2004) wrote the paper on enrichment travelers, Sanchez and Sutton-Brady (2004) examined the celebrity personality impact on sports endorsement, Sytnyk (2004) evaluated the customer satisfaction by using a case study on electricity supply in Ukraine, Tsoi (2003) used the imitation model for tourism market research in Russia, Venugopal (2003) used a multilevel sampling plan for 260 buyers in India to learn their buying preferences, Vrontis (2003) introduced the adaptive process for UK multinational companies through a questionnaire survey.

Four papers originated from the University of Zaragoza in Spain. The government of Aragon and the Science and Technology Ministry of Spain, sponsored these projects at the University of Zaragoza. Flavian et al (2003) analyzed the market orientation and business performance of the Spanish publishing companies, Fraj-Andres (2003) studied the values and lifestyles of 573 people, Juste and Redondo (2003) did the empirical analysis of 107 franchisors and 102 franchisees on their distribution operations in Europe, Martinez and Montaner (2003) examined the characteristics of deal-prone consumers. In addition, Brewer and Suchan (2001) provided a comprehensive atlas of the US Census 2000 data, of 281 million US citizens in the visual-mapping format.

\section{DOMINICAN COLLEGE ${ }^{1}$}

In the fall semester of 1988, the Dominican College student population was about 1,400 when this author joined the Division of Business Administration as an Associate Professor in Computer Information Systems (CIS). The Business Division offers six Bachelor of Science majors: Accounting, Business Administration, CIS, Economics, 
Health Services Administration, and Management. Within the Management major, five areas of specialization are: Financial Management, Human Resource Management, Information Systems Management (MIS), International Management, and Marketing Management. As of the spring semester of 2005, the College's student population is about 1,850, with 70 CIS/MIS majors and 450+ business majors. The College is located 14 miles northwest of New York City. Other academic programs include Arts and Science, Education, Nursing, Occupation Therapy, Physical Therapy, and Social Science. Master degrees are offered in Education, Nursing, Physical Therapy, and Occupational Therapy. Recently a Doctor in Physical Therapy program has been approved by the State of New York.

This author served as the Director of the Business Division from 1990 to 1996. A revised International Management curriculum was developed with inputs from the faculty of Arts Science, Social Sciences and CEOs in the industry in 1991 (Hsu 1995). This author taught BU 325 International Business, MK 326 Global Marketing, MG 355 International Management, and MG 366 Global E-Commerce (Hsu, 2003) since 1992. Student enrollment has steadily increased. A full-time marketing professor was hired to cover most courses in Marketing. There are nine courses in the Marketing curriculum. This author also taught in the Marketing curricula as follows:

\section{MK 114 Basic Marketing}

In summer 2001, 10 people enrolled. Short case studies were done and presented in class including Coke, Citigroup, and McDonald. Christina Ceccarelli, a Fermentation Coordinator of American Home Products, now Wyeth Lab, expressed very strong interest in marketing. Tracey O'Keefe, a student studying in a college in Maryland, got a summer job with Deutsche Bank, New York City while taking this course.

\section{MG 345 Marketing Management}

Rian Smith did a case study for possible recruitment of local high school students in 1992. He got information from Peterson's guide, various high school catalogs, and personal contacts. A marketing plan was made and summarized. Ralph Pena, who worked for Goldman Sachs, did a case study on trading floor marketing, management, and operational issues in 1993.

\section{MK 326 Global Marketing}

This course was offered 10 times since 1994, starting with 4 students in 1994 and ending with 30 students in spring 2005. Total number of students taught: 149. Many in-class assignments were given: Streets-98, Global Trade, Trade Opportunity, Siebel System, and Business Travel. Students work in groups to develop team building, problem solving, and interpersonal skills. Many case studies were covered, including Japanese Management (Hsu 1997) and Hong Kong, Tokyo, and Shanghai triangular economy (Hsu 2001).

\section{MK 441 Marketing Research}

Karen Guilfoyle and Karen Roche did a case study for possible recruitment of students from Ireland. It consists of a survey of the high schools in Ireland, and a list of their Irish friends, relatives, and colleagues. The list is quite extensive. When traveling to Ireland in 1991, this author was able to make contacts based upon the case study. Dawn vanEmburgh did a case study to recruit non-returning students. These students (about 400 folders were available) took one, two, or many courses at Dominican in the past but did not continue. A marketing plan was made from this case study. Then a letter was drafted and sent to all 400 students, followed by phone calls. Eight people responded and 3 people registered.

\section{BARUCH COLLEGE ${ }^{2}$}

In the summer of 2004, this author taught "MKT 9702 Marketing Research", at the Zicklin School of Business, Baruch College, of the City University of New York, New York, New York. The course is offered in the Master Degree of Business Administration (MBA) program with 37 students enrolled. Students are working professionals, managers, or vice presidents in advertising, brokerage, cosmetics, engineering, fashion, food, 
healthcare, law, media, NYC government, pharmaceutical, public relations, publishing, social research, technology, transportation, and US government. McDaniel and Gates' text (2004) was used as the textbook. The book is very clear on major topics: marketing research industry, problem definition, research process, secondary database, qualitative research, survey research, primary data collection, measurement concept, questionnaire design, basic sampling, sample size, data processing, statistical testing, bivariate correlation regression, multivariate data analysis, quantitative research, communicating results, managing and ethics issues. A student version of the SPSS software, Version 11 is enclosed with the textbook. Students were able to install SPSS on their home PCs and do the quantitative analysis. Real-world cases were covered in class, using materials from books, magazines, Harvard, Cranfield, and Thunderbird (2005) cases in addition to Internet research. Many students majored in MBA, but few indicated interest in a Ph.D. in Marketing. Advanced marketing research papers were shown in class to generate interest among the potential students, JMR (2003). In addition to two homework assignments and a midterm exam, six final group projects were assigned. Each project had six people in the group, with a project manager. The class met Monday, Wednesday and Thursday, from 6:00 to 8:00 p.m. every week for 6 weeks. After the midterm exam, thirty minutes or more were given to allow group members to discuss their final project in class. Students also spent many more hours on their own to write the final paper (25 or more pages) and prepare the MS PowerPoint slides (20 to 40 slides).

For the final written paper: (1) purpose of the research, (2) definition and terminology (3) questionnaire form, data collection, SPSS analysis, and (4) conclusion and future work, were graded as 10 points each. The oral presentation had these four items with 10 points each. In addition, (5) the ability to ask relevant question and (6) the ability to answer correctly were graded as 10 points each for a total of 100 points. Student received the same grade for the written paper, but different grade for their oral presentation.

Six final projects were completed and presented:

- $\quad$ ARTec Colorist Collection: The \#1 hair color wash-out/fade prevention maintenance system by salons, hair colorists and stylists worldwide. An online survey was analyzed consisting 118 samples. Using SPSS, factor and regression analysis was made to get demographic data about the consumer attitudes and behaviors. Five specific recommendations were given for future marketing effort.

- Baruch College Bookstore: The research was done to find ways to increase sales for the bookstore, to identify reasons to retain customers, etc. Using SPSS, frequency tables were made on different pricing, online competition, store staff services and many other related issues.

- $\quad$ Beth Israel Continuum Center for Health and Healing: This study obtained information on the views and attitudes of patients receiving complementary alternative medicine (CAM). Using SPSS, segmentation analysis was made to find out the motivation factors of the patients to use CAM.

- $\quad$ Blockbuster Video: The research examined Blockbuster, NetFlix, and Video on Demand preferences and attitudes among consumers, and awareness of Blockbuster advertising and promotions. Using SPSS, onesample test, segmentation analysis, and Chi-Square test were made to get information on the rental consumer behavior.

- $\quad$ HBO Customer Satisfaction Study: A marketing research plan was made to deliver HBO tangible insights with regard to their four core service areas. Using SPSS, satisfaction data in programming, scheduling, and price were analyzed. The findings provide HBO with a clear understanding of the perceptions and opinions held by existing customers.

- $\quad$ iPod: surveyed the owners of portable music players, made by Sony and Apple. SPSS was used to do basic and segmentation analysis. The owners of the portable music players predominately owned Sony music players but wanted to purchase iPod as their next preferred product.

The class of 36 people made oral presentations in a period of two hours. Only one person dropped out. The final project was successful and the class did well. 


\section{NEW JERSEY BULK MAIL CENTER ${ }^{2}$}

In the spring 2005, this author taught a course "Marketing Research”, at the New Jersey Bulk Mail Center, Jersey City, NJ to 6 people. The class ran on ten Tuesday evenings from 6:30 to 9:30 p.m. McDaniel and Gates' text (2004) was used. Due the fact the time period was shorter and weather condition was bad, the amount of material covered was much less than the course taught at Baruch College. Final projects are in progress:

- $\quad$ Analyzing Customer Data using SPSS Software for an Internet Service Firm

- $\quad$ Marketing Research in Attracting Small Business Owners

- $\quad$ Marketing Research in Human Resource Recruitment

- $\quad$ Marketing Research in Providing Better Services at the NJ Bulk Mail Center

In the fall 2004, this author taught a course "Project Management”, at the same location to 12 people. They are mostly engineers or managers in technology or financial service firms. Six final projects were made using MS Project software (Hsu 2004). Both of these courses were offered to the members of the Institute of Electrical Electronics Engineer (IEEE), North Jersey Section through its Education Committee. The purpose is to retrain engineers to get new skills as project managers or market researchers. This author has been teaching courses in C, $\mathrm{C++}$, Java, Advanced Java, Project Management, and Marketing Research, with IEEE North Jersey Section Education Committee since 1993. Enrollment was 20 in Java class (Hsu 2004).

\section{CONCLUSION}

Courses in Basic Marketing, Marketing Management, Global Marketing, and Marketing Research were taught to 207 people in three different organizations since 1991 by this author. Students range from 18 to 65 years old. For a large class, lectures, homework assignments, midterm, and final exam are the norm. For a small class, case studies and oral presentations give the best chance for success. In-class team projects are used for all courses. The use of PC software (disk or CD-ROM), Internet search, in-class discussions using Business Week, Economist, Financial Times, Forbes, Fortune and videotapes viewing, stimulate much interest.

\section{ACKNOWLEDGMENTS}

Thanks are given to Dr. Clare Pennino, Director, and the faculty of the Business Division of Dominican College for their encouragement. The fall 2005 sabbatical award and the faculty research grant are appreciated. This author thanked Dr. Gary Soldow of Baruch College for the opportunity to teach the Marketing Research course. Thanks are also given to Bhanu Chivakula, Chair, IEEE North Jersey Section Education Committee for making arrangement for hotel reservations and student registrations. Thanks are bestowed to Joseph Pearson and Dilip Pandya of New Jersey Bulk Mail Center for providing the classroom space. It has been a very rewarding experience.

\section{ENDNOTES}

1. Full-time position.

2. Part-time position.

\section{REFERENCES}

1. Brewer, C. A. and Suchan, T. A., Mapping Census 2000: the Geography of US Diversity, ESRI, Redlands, CA (2001)

2. Cho, Y. and Ha, J., Measuring Consumer Behavior, \#155, Program Proceeding of the European Applied Business Research Conference, ISSN 1539-8757, The CIBER Research Institute, Littleton, CO, June (2004)

3. Chow, C.S.F., Tang, E.P.Y., and Fryxell, G.E., Can Eco-Labels attract buyers?, \#245, Program Proceeding of the European Applied Business Research Conference, ISSN 1539-8757, Western Academic Press, Littleton, CO, June (2003) 
4. Chuchinprakarn, S., On-Line Shopping Intentions, \#202, Program Proceeding of the European Applied Business Research Conference, ISSN 1539-8757, The CIBER Research Institute, Littleton, CO, June (2004)

5. JMR: Journal of Marketing Research, edited by W. A. Kamakura, American Marketing Association, Chicago, IL, Volume XL, Number 4, November (2003).

6. Juste, M. V. B. and Redondo, Y. P., Long Term Relationship in Franchised Distribution Systems, \#507, Program Proceeding of the European Applied Business Research Conference, ISSN 1539-8757, Western Academic Press, Littleton, CO, June (2003)

7. Ergin, E. A., Ozdemir, H., and Ozsacmaci, B., The Family Purchasing Decision, \#168, Program Proceeding of the European Applied Business Research Conference, ISSN 1539-8757, The CIBER Research Institute, Littleton, CO, June (2004)

8. $\quad$ Eriotis, N., Kapareliotis, I., Panigyrakis, G., Vasiliou, D., and Ventoura, Z., Does Marketing Increases Company's Power?: The Profits Approach, \#300, Program Proceeding of the European Applied Business Research Conference, ISSN 1539-8757, The CIBER Research Institute, Littleton, CO, June (2004)

9. $\quad$ Flavian, C., Fuster, A., and Polo, Y., Market Orientation and Business Performance, \#493, Program Proceeding of the European Applied Business Research Conference, ISSN 1539-8757, Western Academic Press, Littleton, CO, June (2003)

10. Fraj-Andres, E., The Ecological Consumer Behavior, \#542, Program Proceeding of the European Applied Business Research Conference, ISSN 1539-8757, Western Academic Press, Littleton, CO, June (2003)

11. Harvard Business Review, http://www.harvardbusinessonline.org, Cranfield Business School, http://www.ecchatbabson.org, Thunderbird International School of Management, http://www.t-bird.edu, (2005); private communication (2003)

12. Hsu, D. K., Multimedia Software Applications for International Management Curriculum, Proceedings of the Eleventh Annual Eastern Small College Computing Conference, pps. 167 - 171, Iona College, New Rochelle, NY, (1995)

13. Hsu, D. K. and Wirth, I., Japanese Firms in the New York Tri-State Region: Trends in Managerial Styles, in Interactive Teaching and Learning, Wacra $14^{\text {th }}$ International Conference proceedings, edited by Hans E. Klein, pps. 577 - 584, Omni Press Inc, Madison, WI, December (1997)

14. Hsu, D. K., Hong Kong, Tokyo, and Shanghai Triangular Economy, Program of the American Association Chinese Studies, Volume 43, p. 14, University of Chicago, Chicago, IL, Oct. (2001)

15. Hsu, D. K., Case Studies in Business, Finance, International Management, and Marketing Courses, in Interactive Teaching Learning in a Global Context, edited by Hans Klein, pps. 215-222, Omni Press, Madison, WI, January (2003)

16. Hsu, D. K., Case Studies in Programming and System Courses, \#3455, Proceeding of the ISECON conference, ISSN 1542-7382, Newport, RI, April (2004)

17. Hsu, D. K., Case Studies in Project Management, IT Project+, MS Project and Global E-Commerce Projects, \#142, Program Proceeding of the European Applied Business Research Conference, ISSN 1539-8757, The CIBER Research Institute, Littleton, CO, June (2004)

18. Jee, K. and Kim, M., Empirical Analysis on Marketing Strategy Factors for the Development of Korea's Portable Internet Services Market, \#370, Program Proceeding of the European Applied Business Research Conference, ISSN 1539-8757, The CIBER Research Institute, Littleton, CO, June (2004)

19. Khatibi, A., Thyagarajan, V., Ismail, M., and Hishamudin, I., E-Commerce Adoption in Malaysia: Problems and Barriers, \#337, Program Proceeding of the European Applied Business Research Conference, ISSN 1539-8757, Western Academic Press, Littleton, CO, June (2003)

20. Manna, D. R. and Smith, A. D., Measuring the Theoretical Paradigm Shift from Marketing Mix to Relational Marketing, \#128, Program Proceeding of the European Applied Business Research Conference, ISSN 15398757, Western Academic Press, Littleton, CO, June (2003)

21. Martinez, E. and Montaner, T., Some Characterizations of Deal-Prone Consumers, \#489, Program Proceeding of the European Applied Business Research Conference, ISSN 1539-8757, Western Academic Press, Littleton, CO, June (2003)

22. McDaniel, C. and Gates, R., Marketing Research", $6^{\text {th }}$ Edition, John Wiley and Sons Inc, Hoboken, NJ (2004) 
23. Mina, M., Mobile Services’ User Segments among Finnish Banking Customers, \#193, Program Proceeding of the European Applied Business Research Conference, ISSN 1539-8757, Western Academic Press, Littleton, CO, June (2003)

24. Mitchell, M. and Yates, D.W., A Survey at a County Fair, \#281, Program Proceeding of the European Applied Business Research Conference, ISSN 1539-8757, Western Academic Press, Littleton, CO, June (2003)

25. Mujika-Alberdi, A. and Garcia-Arrizabalaga, I., A Comparative Study of the Attitude toward Advertising, \#327, Program Proceeding of the European Applied Business Research Conference, ISSN 1539-8757, The CIBER Research Institute, Littleton, CO, June (2004)

26. Radas, S., Analysis of Empirical Survey of Innovations Development in a Transition Economy: the Case of Croatia, \#235, Program Proceeding of the European Applied Business Research Conference, ISSN 15398757, Western Academic Press, Littleton, CO, June (2003)

27. Ray, N., The Old Men and the Sea: Literary Tourism, Heritage Tourism, and Ecotourism, \#138, Program Proceeding of the European Applied Business Research Conference, ISSN 1539-8757, The CIBER Research Institute, Littleton, CO, June (2004)

28. Reardon, J. and Vida, I., Factors Underlying Domestic Purchasing Behavior in Transitional Economies, \#255, Program Proceeding of the European Applied Business Research Conference, ISSN 1539-8757, Western Academic Press, Littleton, CO, June (2003)

29. Sanchez, R. and Sutton-Brady, C., Does Sport Matter?: An Analysis of the Personality of Sport, \#214, Program Proceeding of the European Applied Business Research Conference, ISSN 1539-8757, The CIBER Research Institute, Littleton, CO, June (2004)

30. Stevenson, T. H. and Plath, D. A., Exploring the Substantiality and Differentiability of an Emerging Segment, \#439, Program Proceeding of the European Applied Business Research Conference, ISSN 15398757, Western Academic Press, Littleton, CO, June (2003)

31. Sytnyk, T., Evaluating Customer Satisfaction in a Monopoly Market, \#304, Program Proceeding of the European Applied Business Research Conference, ISSN 1539-8757, The CIBER Research Institute, Littleton, CO, June (2004)

32. Tsoi, M. Y., The Using of Imitation Model for Tourism Market Research, \#157, Program Proceeding of the European Applied Business Research Conference, ISSN 1539-8757, Western Academic Press, Littleton, CO, June (2003)

33. Vengopal, P., Brand Decisions: A Study of Rural Buyers in India, \#297, Program Proceeding of the European Applied Business Research Conference, ISSN 1539-8757, Western Academic Press, Littleton, CO, June (2003)

34. Vrontis, D., Adaptation or Standardization?, \#168, Program Proceeding of the European Applied Business Research Conference, ISSN 1539-8757, Western Academic Press, Littleton, CO, June (2003) 